\title{
Plant, small mammal, and avian diversity following control of honey mesquite
}

\author{
KENNETH R. NOLTE AND TIMOTHY E. FULBRIGHT
}

Authors are graduate research fellow, Caesar Kleberg Wildlife Research Institute, Campus Box 218, Texas A\&M University-Kingsville, Kingsville, Tex. 78363; and professor, Caesar Kleberg Wildlife Research Institute, Campus Box 218, Texas A\&M University-Kingsville, Kingsville, Tex. 78363.

\begin{abstract}
The effects of herbicide applications to kill honey mesquite (Prosopis glandulosa Torr.) on community diversity are poorly documented. Our objective was to test the hypothesis that herbicide application to kill honey mesquite would reduce plant and vertebrate species richness and diversity. A 1:1 mixture of triclopyr $\{[(3,5,6-t$-trichloro-2-pyridinyl) oxy]acetic acid $\}+$ picloram (4-amino-3,5,6-tricholopicolinic acid) was applied to three 13-ha plots during 1992 and to 3 additional plots in 1993. Mesquite and forb canopy cover in the zone $\leq 1 \mathrm{~m}$ from the soil surface were lower within treated plots than in control plots $(n=3)$ following the 1992 and 1993 treatments. Grass canopy cover did not differ between herbicide-treated plots and control plots. Vegetation species richness and evenness, Shannon's index, beta diversity, and proportion of rare plant species did not differ between controls and sites treated during 1992 and 1993. Rodent and avian relative frequency, richness, and diversity were not different on 1992 herbicide treatment plots and controls. Based on these results, application of triclopyr + picloram in mesquite-mixed grass communities in the Texas Coastal Bend does not appear to reduce plant and vertebrate species richness and diversity within the first 2 years after treatment. However, our results should be interpreted cautiously because (1) annual rainfall was $16 \%$ above the annual average during the study and (2) limited replication possibly reduced statistical power to detect differences.
\end{abstract}

Key Words: herbicides, Prosopis glandulosa, triclopyr + picloram, species richness

Increasing societal concern regarding the value of biological diversity has influenced the passage of more than 29 Federal laws regulating the use of biological resources in the United States. This trend will likely continue into the future, resulting in creation of laws and regulations involving biological diversity which will influence rangeland managers for decades (West 1993). Developing management technologies that maintain biodiversity is a desirable objective for range and wildlife managers because of the value that society places on biodiversity, and biological and economic factors.

Biological reasons for maintaining biodiversity are multiple. Primary productivity in more diverse plant communities is more

Research was supported by the Rob and Bessie Welder Wildlife Foundation. This is Welder Wildlife Foundation Contribution 448.

Manuscript accepted 9 Jan. 1996. resistant to perturbations such as drought and recovers more fully following such perturbations (Tilman and Downing 1994). Greater plant species diversity has been associated with greater biomass stability through time, greater resistance to grazing by single species of ungulates, and with greater resilience after grazing (McNaughton 1985). Plant root mass, organic matter, and monosaccharide content of dry aggregates were lower under monocultures of introduced grasses than under more diverse native plant communities in Canada (Dormaar et al. 1995).

Biological diversity increases the potential economic value of rangeland for recreational enterprises. For example, bird-watching in the 80 ha Sabal Palm Sanctuary in Texas generates $\$ 1.28$ million/year (McBryde 1994). Good hunting potential contributes about $\$ 445 /$ ha to land prices in the Texas Hill Country (Pope 1985).

Treatments that increase grasses for cattle and concomitantly maintain plant, mammal, and avian diversity would possibly resolve conflicts between biodiversity concerns and increasing forage for cattle. Reported impacts of herbicicle treatments on plant and vertebrate diversity vary. Scifres and Koerth (1986) reported that effects of herbicide treatment on forb cover and diversity varied depending on herbicide dosage, range site, and rainfall. In British Columbia, treating a Douglas fir (Pseudotsuga menziesii (Mirb.) Franco.) plantation with glyphosate did not affect small mammal abundance (Sullivan and Sullivan 1982). In contrast, treating clearcuts in Maine with glyphosate reduced abundance of birds and small mammals (Santillo et al. 1989a, $1989 \mathrm{~b})$. In Oregon, density and diversity of birds were not affected by application of 2,4,5-T (Morrison and Meslow 1984). Rodgers and Sexton (1990) determined that bird species most closely associated with grass abundance were present in greatest numbers in pastures treated with 2,4-D.

Applying a 1:1 mixture of triclopyr $\{[(3,5,6$-trichloro-2pyridinyl) oxy]acetic acid + picloram (4-amino-3,5,6-tricholopicolinic acid) at appropriate soil temperatures and time is recommended for controlling mesquite (Prosopis glandulosa Torr.) in Texas (Welch 1993). Our overall objective was to test the hypothesis that application of triclopyr + picloram in a mesquitemixed grass community would reduce species richness and diversity relative to untreated plots. Specific objectives were to determine the effects of herbicide application on (1) plant species richness, evenness, diversity (alpha and beta), rareness, and percent canopy cover; (2) small mammal relative density, relative frequency, richness, and diversity; and (3) avian relative frequency, richness, and diversity. 


\section{Study Area}

This research was conducted on the Rob and Bessie Welder Wildlife Foundation Refuge in northern San Patricio County, Texas. Climate of the region is humid, subtropical with hot summers and cool winters. Precipitation peaks occur during spring and the fall hurricane season. Annual rainfall varied from $38.0-128.4 \mathrm{~cm}$ between 1957 and 1993 with a mean of $88.9 \mathrm{~cm}$. Rainfall during $1992(128.4 \mathrm{~cm})$ and $1993(102.8 \mathrm{~cm})$ was above the annual average of $88.9 \mathrm{~cm}$ for the Welder Refuge. Data were collected during a 2-year period of above average rainfall and do not reflect average conditions, thereby limiting applicability within other sites or habitats. The primary soil in the study area was a fine, montmorillonitic clay of the Victoria series (Udic Pellustert) with a band of fine, mixed hyperthermic clay of the Edroy series (Vertic Haploquoll) associated with treatments located adjacent to a drainage basin (Drawe et al. 1978).

Vegetation of the study area was the mesquite-mixed grass community described by Drawe et al. (1978). The mesquitemixed grass community was composed of moderate stands of honey mesquite interspersed with dense mottes of chaparral and interstitial areas of grass. Common brush species included huisache (Acacia smallii (L.) Willd.), spiny hackberry (Celtis pallida Torr.), tasajillo (Opuntia leptocaulis DC.), agarito (Mahonia trifoliata Moric), lotebush (Condalia obtusifolia Hook.), lime pricklyash (Zanthoxylum fagara Mill.), and pricklypear cactus (O. lindheimeri Engelm.). Dominant grasses included Texas wintergrass (Stipa leucotricha Trin. \& Rupr.), plains bristlegrass (Setaria leucopila Scribn. \& Merr.), and vine mesquite (Panicum obtusum H. B. K.). Dominant forbs included upright prairie coneflower (Ratibida columnaris Sims), western ragweed (Ambrosia cumanensis DC), and violet ruellia (Ruellia nudiflora Engelm. \& Gray). Plant nomenclature follows Hatch et al. (1990).

\section{Methods}

\section{Experimental Design}

A randomized, complete-block design was used with 3 treatments: controls (no treatment applied), treated with herbicide in 1992 only, treated with herbicide in 1993 only, and 3 blocks with each of the 3 treatments randomly assigned within each block. Experimental units were 13.3 ha $(365 \times 365 \mathrm{~m})$ in size. Experimental units within a block and between successive blocks were $\geq 100 \mathrm{~m}$ apart.

\section{Herbicide Application}

A 1:1 mixture of triclopyr $\{[(3,5,6$-trichloro-2-pyridinyl) oxy]acetic acid) + picloram (4-amino-3,5,6-tricholopicolinic acid) was applied on 21 June 1992 and 16 June 1993 by helicopter at a rate commonly used on mesquite in southern Texas ( $\mathrm{J}$. Mutz, J\&M Helicoptor Serv. Inc., pers. commun.). Herbicide was applied at 47.5 liters/ha with 1.9 liters each of picloram and triclopyr in a 1:5 diesel oil emulsion. A drift retardant (38 F, a formulation consisting primarily of polyacrylamide) was used to minimize overspray and a commercial surfactant (a blend of parrafin oil, polyol fatty acide esters, polycthoxylated cstcrs, and ethoxylated alkyl aryl phosphate esters) was used to increase absorption. Herbicide was applied in 12-m-wide swaths with flaggers at both ends of the plot to ensure complete coverage. The herbicide was applied at $97 \mathrm{~km} / \mathrm{hr}$ when wind speeds were $\leq 8$ $\mathrm{km} / \mathrm{hr}$. To achieve maximal kill, the herbicide was applied when soil temperatures were $\geq 22^{\circ} \mathrm{C}$ for at least 1 week.

\section{Vegetation}

Ten 50-m-long vegetation transects were established within each replication of each treatment by a stratified random method and permanantly marked (Chambers and Brown 1983). Herbaceous and woody plant canopy cover and relative frequency were estimated during April 1992 and 1993 before herbicide treatments and again during October 1992 and 1993 by a modified point-intercept method (Wray and Whitmore 1979, Tazik et al. 1991). At 1-m intervals along each transect, a thin rod divided into $0.1-\mathrm{m}$ increments was used to record the total number of contacts by vegetation species in each of 3 height classes $(\leq 1 \mathrm{~m}$, $>1-3 \mathrm{~m}$, and $>3 \mathrm{~m}$ ).

Plant species richness, alpha diversity, and beta diversity were calculated with canopy cover and relative frequency data (Biondini et al. 1989). Alpha diversity was quantified with Shannon's index using natural logs (Pielou 1975). Beta diversity was calculated as mean dissimilarity (100-mean similarity) (Scheiner 1992). Similarity was calculated between all possible pairs of transects within each treatment $(n=45)$ with Jaccard's similarity index (ISi,j) (Janson and Vegelius 1981).

$$
I S_{i j}=\frac{\left(M_{c}\right)}{\left(M_{a}+M_{b}+M_{c}\right)} \times 100
$$

where $I_{i, j}=$ Similarity index value, $M_{c}=$ Number of species common to $i$ th and $j$ th transects, $M_{a}=$ Number of species unique to the ith transect, and $\mathrm{M}_{\mathrm{b}}=$ Number of species unique to the jth transect.

Species evenness was calculated as:

$$
\text { Evenness }=\frac{\text { Shannon's index }}{\ln \text { (species richness) }}
$$

Proportions of rare species were compared in control and treated plots before and after herbicide application. A species was considered rare when it accounted for $\leq 1 \%$ canopy cover.

Mean percent canopy cover was also compared among treatments within 5 vegetation classes (grass, forb, mesquite, other woody vegetation, and cacti), and for selected species of forbs which were identified as having some value as food for wildlife such as white-tailed deer (Odocoileus virginianus Raf.) (Chamrad and Box 1968, Everitt and Drawe 1974, Arnold and Drawe 1979, Warren and Krysl 1983).

\section{Small Mammals and Birds}

Small mammals were trapped during March 1992, December 1992, and December 1993 with 49 Sherman live traps in a $7 \times 7$ grid with a 10-m spacing between traps. All treatments within a given block (pasture) were trapped simultaneously to minimize confounding effects caused by time or changes in weather patterns. Traps were baited before dark with a mixture of rolled oats and peanut butter and were checked the following morning. To minimize mortality caused by red imported fire ants (Solenopsis invicta), trapping was conducted when night-time temperatures were $<22^{\circ} \mathrm{C}$ (Masser and Grant 1986, Porter and Tschinkel 1987, Flickinger 1989). Traps remained closed during the day to prevent incidental captures. Captured individuals were identified to species, toe-clipped using 1 toe to identify recaptures (Day et al. 
1980), and released. Trapping was conducted for 5 consecutive days in each treatment in each block.

Fire ant densities were quantified within each of the 9 treatments during each trapping effort to determine if fire ant populations varied among treatments. The number of active ant colonies was recorded within a 5-m-wide belt transect centered along each of the 7 lines within each trapping grid. Densities were presented as colonies/ha and were compared to small mammal densities.

Relative density of small mammals was estimated by calculating the percent success rate of captures for each grid within each treatment. Relative frequencics werc calculated by dividing the number of each species captured by the total number of captures. Shannon's index (using natural logs) was calculated from the proportions of each species captured.

Line transects were used to determine bird species composition in treated and control areas (Emlen 1970, Eberhardt 1978, Wakely 1987). Two 300-m transects were placed within each treatment in each block. Transects were traversed the first 3 hours after sunrise and the last 3 hours before sunset. Sampling was conducted during February and March 1992 and 1993. Transects in each treatment were traversed 9 times $(5.4 \mathrm{~km})$. Avian species relative frequency and Shannon's index were calculated from the proportions of each species observed.

\section{Statistical Analyses}

Pre-treatment analyses for 1992 were performed with $t$-tests comparing vegetation means in control and treated (in 1992 only) plots for pretreatment (April 1992) sampling. Repeated measures ANOVA for the 3 post-treatment sampling dates (October 1992, April 1993, October 1993) was used to determine if the vegetation attributes differed significantly $(P \leq 0.05)$ between treatments following herbicide application. Vegetation analyses for the 1993 herbicide treatment involved $t$-tests comparing the control and treated (in 1993 only) plots for the pre-treatment (April 1993) and post-treatment (October 1993) sampling dates.

Relative density, species richness, and diversity means for small mammals were compared using $t$-tests for pre-treatment data (March 1992) and using repeated measures ANOVA on the post-treatment data (December 1992, December 1993) for the 1992 herbicide treatment. Analysis of the 1993 treatment involved comparing the control and herbicide treatment means using $t$-tests for the pre-treatment (December 1992) and posttreatment (December 1993). Avian relative frequencies, species richness, and diversity were compared using $t$-tests for the pretreatment (March 1992) and post-treatment data (March 1993). Avian community attributes were compared only for the 1992 herbicide treatment.

For all repeated measures ANOVA block $\times$ treatment was used for the error term. Differences between sample dates and treatment $\times$ sampling date interactions were tested during all repeated measures analyses. When interactions occurred, contrasts were performed to determine where differences occurred. All statistical analyses were performed using SAS (Statistical Analysis Institute 1988) and percentage or proportion data were arcsin squareroot transformed before statistical analyses (Snedecor and Cochran 1967:327).

\section{Results}

\section{Vegetation}

Herbicide treatments applied in 1992 and 1993 reduced $(P<0.05)$ canopy cover of mesquite and forbs in the $1 \mathrm{~m}$ strata (Tables 1 and 2). Herbicide treatment during 1993 reduced $(t=2.98, \mathrm{P}=0.03)$

Table 1. Mean $(\mathrm{n}=3$ ) vegetation canopy cover $(\%)$ for different height classes within herbicide-treated and untreated (control) plots before and after the 1992 application of triclopyr + picloram to control honey mesquite on the Rob and Bessie Welder Wildlife Foundation Refuge, San Patricio County, Texas, 1992.

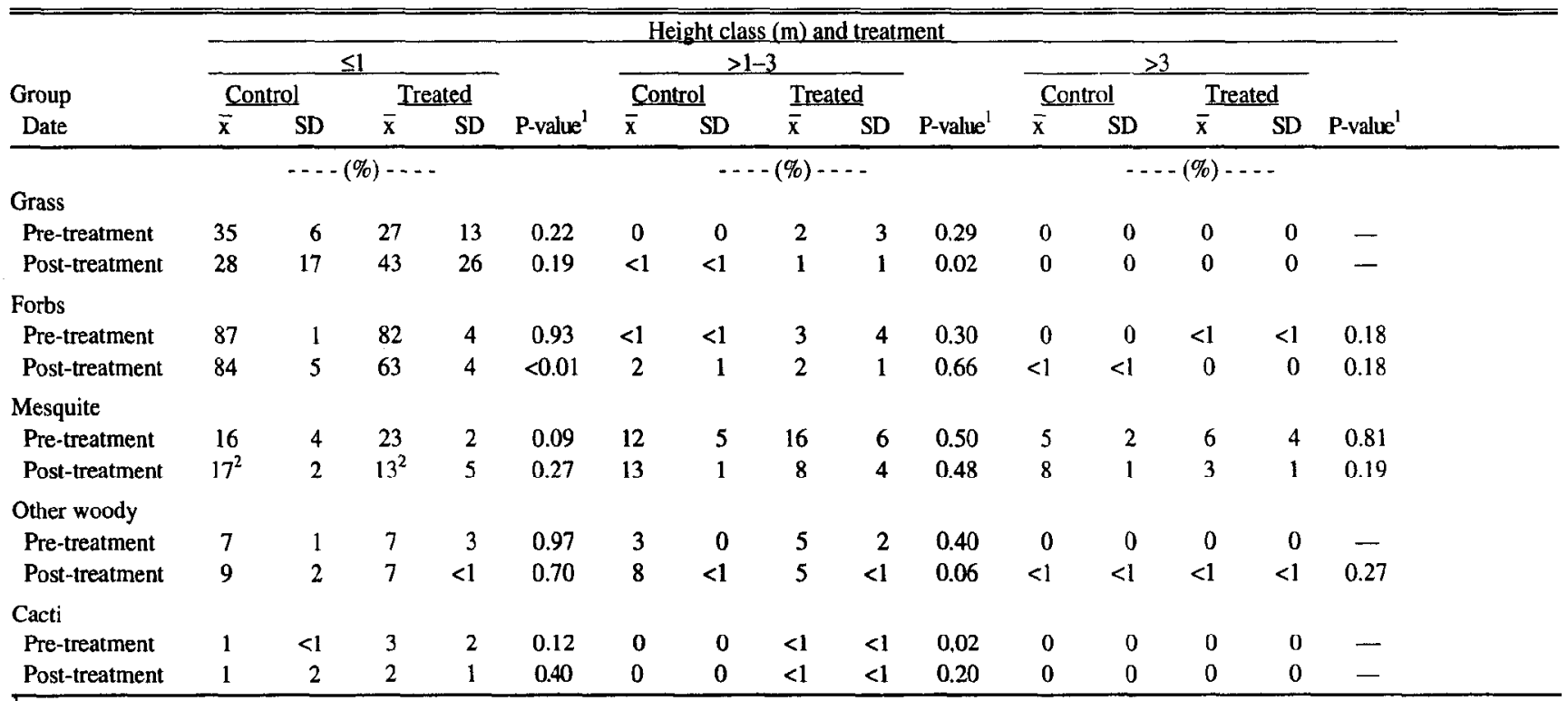

Control and herbicide treatment means were compared using t-tests for pre-treatment data and using repeated measures ANOVA nn the post-treatment data for the 1992 herhicide application.

${ }^{2}$ Interaction $(P=0.04)$ between sampling date and treatment. Cover was less $(P<0.01)$ in treated plots during Apr. 1993, but not different $(P=0.86, P=0.06)$ during Oct. 1992 and Oct. 1993, respectively. 
Table 2. Mean $(n=3)$ vegetation canopy cover $(\%)$ for different height classes within herbicide-treated and untreated (control) plots before and after the 1993 application of triclopyr + picloram to control honey mesquite on the Rob and Bessie Welder Wildlife Foundation Refuge, San Patricio County, Texas, 1993.

\begin{tabular}{|c|c|c|c|c|c|c|c|c|c|c|c|c|c|c|c|}
\hline \multirow{4}{*}{$\begin{array}{c}\text { Group } \\
\text { Date }\end{array}$} & \multicolumn{15}{|c|}{ Height class (m) and treatment } \\
\hline & \multicolumn{4}{|c|}{$\leq 1$} & \multirow[b]{3}{*}{ P-value $^{1}$} & \multicolumn{4}{|c|}{$>1-3$} & \multirow[b]{3}{*}{ P-value ${ }^{1}$} & \multicolumn{4}{|c|}{$>3$} & \multirow[b]{3}{*}{ P-value ${ }^{1}$} \\
\hline & \multicolumn{2}{|c|}{ Control } & \multicolumn{2}{|c|}{ Treated } & & \multicolumn{2}{|c|}{ Control } & \multicolumn{2}{|c|}{ Treated } & & \multicolumn{2}{|c|}{ Control } & \multicolumn{2}{|c|}{ Treated } & \\
\hline & $\overrightarrow{\mathrm{x}}$ & $\mathrm{SD}$ & $\overline{\mathrm{x}}$ & $\mathrm{SD}$ & & $\bar{x}$ & SD & $\overline{\mathbf{x}}$ & SD & & $\overline{\mathrm{x}}$ & SD & $\overline{\mathrm{x}}$ & SD & \\
\hline \multirow{2}{*}{\multicolumn{16}{|c|}{$--(\%)-\cdots$}} \\
\hline & & & & & & & & & & & & & & & \\
\hline Pre-treatment & 45 & 16 & 44 & 4 & 0.12 & $<1$ & $<1$ & $<1$ & $<1$ & 0.07 & 0 & 0 & 0 & 0 & - \\
\hline Post-treatment & 27 & 9 & 28 & 2 & 0.08 & $<1$ & $<1$ & $<1$ & $<1$ & 0.11 & 0 & 0 & 0 & 0 & - \\
\hline \multicolumn{16}{|l|}{ Forbs } \\
\hline Pre-treatment & 88 & 4 & 71 & 18 & 0.04 & 1 & $<1$ & $<1$ & $<1$ & 0.42 & $<1$ & $<1$ & $<1$ & $<1$ & 0.35 \\
\hline Post-treatment & 85 & 5 & 30 & 17 & $<0.02$ & 1 & $<1$ & $<1$ & $<1$ & 0.39 & $<1$ & $<1$ & 0 & 0 & - \\
\hline \multicolumn{16}{|l|}{ Mesquite } \\
\hline Pre-treatment & 15 & 4 & 21 & 4 & 0.01 & 12 & 5 & 19 & 8 & 0.03 & 7 & 3 & 9 & 5 & 0.21 \\
\hline Post-treatment & 17 & 6 & 8 & 1 & 0.03 & 13 & 6 & 2 & 1 & 0.05 & 8 & 4 & 1 & 1 & 0.09 \\
\hline \multicolumn{16}{|l|}{ Other woody } \\
\hline Pre-treatment & 10 & 1 & 9 & 1 & 0.42 & 8 & 1 & 9 & 1 & 0.06 & $<1$ & $<1$ & 1 & $<1$ & 0.19 \\
\hline Post-treatment & 10 & 1 & 5 & $<1$ & 0.07 & 8 & 21 & 4 & 11 & 0.03 & $<1$ & $<1$ & $<1$ & $<1$ & 0.64 \\
\hline \multicolumn{16}{|l|}{ Cacti } \\
\hline Pre-treatment & $<1$ & $<1$ & 2 & 1 & 0.00 & 0 & 0 & $<1$ & $<1$ & 0.17 & 0 & 0 & 0 & 0 & - \\
\hline Post-treatment & $<1$ & $<1$ & $<1$ & $<1$ & 0.12 & 0 & 0 & 0 & 0 & 0.12 & 0 & 0 & 0 & 0 & - \\
\hline
\end{tabular}

Control and herbicide treatment means were compared using $t$-tests for pre-treatment data and using repeated measures ANOVA on the post-treatment data for the 1992 herbicide application.

canopy cover of other woody species in the $>1-3 \mathrm{~m}$ strata. Grass canopy cover did not differ between treatments, except it was slightly greater $(\mathrm{F}=-7.28, \mathrm{P}=0.02)$ in the $>1-3 \mathrm{~m}$ strata following the 1992 herbicide treatment.

Herbicide treatments reduced $(\mathrm{P}<0.05)$ canopy cover of western ragweed; however, cover of this species was lower $(t=5.21, P=0.005)$ before treatment on plots treated in 1993 (Table 3). Herbicide treatment in 1993 resulted in less canopy cover of ozarkgrass (Limnodea arkansana Nutt.) $(t=2.69, \mathrm{P}=0.05)$, Texas wintergrass $(t=2.85, \mathrm{P}=$ 0.04), California loosestrife (Lythrum califomicum Torr. \& Gray) $(t=$ 3.02, $\mathrm{P}=0.03$ ), false globemallow (Malvastrum aurantinicum Gray) $(t$ $=6.69, \mathrm{P}<0.01$ ), and beebalm (Monarda citriodora Small) $(t=3.96, \mathrm{P}$ $=0.01$ ).

Herbicide treatment had little effect on vegetation diversity indices (Table 4). Species evenness differed $(t=-9.24, \mathrm{P}=0.01)$ between control plots and plots treated with herbicide in 1992 before treatment but not after treatment $(t=-0.75, \mathrm{P}=0.53)$. The proportion of rare species was slightly greater $(\mathrm{t}=-10.00, \mathrm{P}=$ 0.01) in plots treated with herbicide in 1992; otherwise vegetation diversity indices did not differ before treatments for the 1992 or 1993 herbicide treatments.

\section{Small Mammals and Birds}

Herbicide-treated plots did not differ significantly $(P>0.05)$ from controls in relative densities of small mammal species or in small mammal species richness and diversity, except that small mammal species richness was greater $(t=-5.56, \mathrm{P}=0.03)$ in treated plots before treatment in 1992 (Tables 5 and 6). During December 1992, fire ant densities ranged from 24 active mounds/ha to $>768$ active mounds/ha but were not significantly different $(P>0.05)$ between treatments. During December 1993, no ant mounds were found while trapping.

There was no significant difference $(P>0.05)$ for relative frequency of bird species between treatments (Table 7). Avian diversity and species richness were not significantly different $(\mathrm{P}$ $=0.77$ and 0.57 , respectively) between control and treated plots (Table 8).

\section{Discussion}

\section{Vegetation}

We did not detect any effect of treating of honey mesquitedominated rangeland with triclopyr + picloram on plant, small mammal, or avian diversity under the conditions of our study during the first 2 growing seasons after treatment. The effects of brush management vary with soil moisture and texture, original plant composition of the site, and timing of treatment (Stoddard et al. 1975). Sites with favorable moisture relationships may result in a lower mortality rate of woody plants (Beasom et al. 1982, Nolte et al. 1994). Therefore, occurrence of above average rainfall during 1992-1993 possibly created a different response by the vegetation to the herbicide application than would have occurred during years with less rainfall.

Herbicide application possibly created a more heterogeneous distribution of vegetation species since evenness was greater in 1992 treated plots before herbicide application but was similar between control and herbicide-treated areas following treatment. The increase in proportion of rare species following herbicide treatment was possibly because reduction in canopy cover of mesquite and dominant forl species gave rare species a competitive advantage for light, nutrients, and moisture.

Grass canopy cover was expected to increase following herbicide application because killing mesquites would reduce competition between mesquites and grasses for soil water. The lack of increase in grass canopy cover following herbicide treatment possibly resulted because rainfall was well above average during the study. Above average rainfall possibly ameliorated competition 
Table 3. Mean ( $\mathrm{n}=3$ ) canopy cover $(\%)$ for select plant species on herbicide-treated and untreated (control) plits before and after application of triclopyr + picloram to control honey mesquite on the Rob and Bessie Welder Wildlife Foundation Refuge, San Patricio County, Texas, $1992-1993$.

\begin{tabular}{|c|c|c|c|c|c|c|c|c|c|c|}
\hline \multirow{3}{*}{$\begin{array}{l}\text { Species } \\
\text { Sampling date }\end{array}$} & \multicolumn{4}{|c|}{1992 Treatment } & \multirow[b]{3}{*}{ P-value ${ }^{1}$} & \multicolumn{4}{|c|}{1993 Treatment } & \multirow[b]{3}{*}{ P-value } \\
\hline & \multicolumn{2}{|c|}{ Control } & \multicolumn{2}{|c|}{ Treated } & & \multicolumn{2}{|c|}{ Control } & \multicolumn{2}{|c|}{ Treated } & \\
\hline & $\overline{\mathbf{x}}$ & $\mathrm{SD}$ & $\overline{\mathbf{x}}$ & SD & & $\overline{\mathrm{x}}$ & SD & $\overline{\mathrm{x}}$ & $\mathrm{SD}$ & \\
\hline & \multicolumn{2}{|c|}{$-\cdots(\%)-\cdots$} & \multicolumn{2}{|c|}{$\ldots(\%)-\ldots$} & & \multicolumn{2}{|c|}{$\cdots(\%)-\ldots$} & \multicolumn{2}{|c|}{$\ldots(\%)-\ldots$} & \\
\hline \multicolumn{11}{|l|}{ Western ragweed } \\
\hline Pre-treatment & 24 & 17 & 2 & 9 & 0.94 & 12 & 6 & 3 & 2 & $<0.01$ \\
\hline Post-treatment & 21 & 8 & 8 & 7 & 0.04 & 22 & 4 & 2 & 2 & $<0.01$ \\
\hline \multicolumn{11}{|c|}{ Bladderpod (Lesquerella lindheimeri (Gray) S. Wats.) } \\
\hline Pre-treatment & 0 & 0 & 2 & 4 & 0.42 & 6 & 8 & $<1$ & $<1$ & 0.30 \\
\hline Post-treatment & 2 & 3 & 4 & 3 & 0.84 & 1 & 2 & 0 & 0 & 0.44 \\
\hline \multicolumn{11}{|l|}{ Ozarkgrass } \\
\hline Pre-treatment & 2 & 2 & 4 & 6 & 0.83 & 20 & 13 & 13 & 10 & 0.76 \\
\hline Post-treatment & 10 & 9 & 9 & 7 & 0.99 & 6 & 8 & 0 & 0 & 0.05 \\
\hline \multicolumn{11}{|c|}{ California loosestrife } \\
\hline Pre-treatment & 0 & 0 & 1 & 1 & 0.08 & 3 & 2 & 1 & 1 & 0.19 \\
\hline Post-treatment & 3 & 1 & 3 & 3 & 0.66 & 2 & 1 & 1 & 1 & 0.03 \\
\hline \multicolumn{11}{|c|}{ Threelobe falsemallow } \\
\hline Pre-treatment & 1 & 1 & 4 & 5 & 0.28 & 8 & 3 & 3 & 2 & 0.09 \\
\hline Post-treatment & 4 & 3 & 5 & 2 & 0.33 & 4 & 1 & 1 & $<1$ & $<0.01$ \\
\hline \multicolumn{11}{|l|}{ Lemon beebalm } \\
\hline Pre-treatment & 2 & 3 & 1 & 1 & 0.73 & 4 & 2 & 1 & $<1$ & $<0.01$ \\
\hline Post-treatment & 2 & 2 & 1 & 1 & 0.12 & 2 & 2 & 0 & 0 & 0.01 \\
\hline \multicolumn{11}{|c|}{ Pink evening primrose (Oenothera speciosa Nutt.) } \\
\hline Pre-treatment & 8 & 2 & 4 & 4 & 0.35 & 15 & 11 & 20 & 13 & 0.44 \\
\hline Post-treatment & 7 & 8 & 8 & 7 & 0.41 & 5 & 3 & 2 & 3 & 0.19 \\
\hline \multicolumn{11}{|c|}{ Groundcherry (Physalis spp.) } \\
\hline Pre-treatment & 0 & 0 & 0 & $\mathbf{0}$ & 0.11 & 1 & 1 & 0 & 0 & 0.62 \\
\hline Post-treatment & 2 & 1 & $<1$ & 1 & 0.76 & 2 & 3 & 0 & 0 & 0.72 \\
\hline \multicolumn{11}{|l|}{ Texas wintergrass } \\
\hline Pre-treatment & 17 & 4 & 2 & 2 & 0.01 & 2 & 4 & 3 & 3 & 0.88 \\
\hline Post-treatment & 2 & 3 & 1 & 1 & 0.16 & 5 & 3 & 0 & 0 & 0.04 \\
\hline \multicolumn{11}{|c|}{ Green-thread (Thelesperma spp.) } \\
\hline Pre-treatment & 0 & 0 & 10 & 17 & 0.33 & 2 & $<1$ & 3 & 3 & 0.16 \\
\hline Post-treatment & $1^{2}$ & 1 & $1^{2}$ & 1 & 0.45 & 1 & 1 & 0 & 0 & 0.71 \\
\hline \multicolumn{11}{|l|}{ Texas broomweed } \\
\hline Pre-treatment & 27 & 20 & 9 & 16 & 0.14 & 3 & 5 & 0 & 0 & 0.44 \\
\hline Post-treatment & 12 & 9 & 1 & 1 & 0.13 & 13 & 11 & 1 & 2 & 0.40 \\
\hline
\end{tabular}

${ }^{1}$ Control and herbicide treatment means were compared using $t$-tests for pre-treatment data and using repeated measures ANOVA on the post-treatment data for the 1992 herbicide application. Analysis of the 1993 treatment involved comparing the control and herbicide treatment means using t-tests for the pre-treatment and post-treatment data.

${ }^{2}$ Significant interaction $(\mathrm{P} \leq 0.05)$ between sampling date and treatment. Green-thread cover was greater $(\mathrm{P}=0.02)$ in control sites during Apr. 1993 .

between grasses and mesquite for soil water. Portions of the study area were inundated with water for extended periods, resulting in establishment of semi-aquatic vegetation in isolated low-lying or poorly drained areas. Finally, the high degree of variability in the data reduced the probability of detecting significant differences.

The $43 \%$ reduction in mesquite cover, across height classes, following the 1992 herbicide treatment was less than the expected reduction of $>70 \%$ (J. Mutz, J\&M Helicopter Serv. Inc., pers. commun.). Favorable soil moisture conditions were one likely reason for this. In addition, size and structure of mesquite varied among plots. Some sites were dominated by solitary shrubs while other sites also had understories comprised of mesquite. The latter situation resulted in some of the understory mesquite being protected from the aerial herbicide application. Sites dominated by spatially separate individuals appeared to have greater kill rates than those sites with a well defined understory of mesquite.
The variation, possibly caused by site differences, appeared to mask the effects of the herbicide. Another possible confounding factor was that the study areas were comprised of clay soils. Dahl et al. (1971) stated that picloram was $20 \%$ less efficient at killing mesquite on clay soil. Any combination of the above factors may have influenced the lower than expected kill rate for mesquite.

Herbicide application appeared to have positive and negative impacts in relation to the selected herbaceous species examined. The reduction in western ragweed canopy cover following the 1992 herbicide treatment was possibly detrimental to wildlife habitat. Western ragweed is an important source of food for white-tailed deer and many species of birds including northern bobwhites (Colinus virginianus L.) (Webb and Guthery 1983). The reduction of Ozarkgrass and Texas wintergrass canopy cover following the 1993 treatment was undesirable in that Texas wintergrass provides important cool-season forage for cattle. Both 
Table 4. Mean ( $=3$ ) plant species richness, evenness, Shannon's index, beta diversity, and species rareness on herbicide-treated and untreated (control) plots before and after application of triclopyr + picloram to control honey mesquite on the Rob and Bessie Welder Wildlife Foundation Refuge, San Patricio County, Texas, 1992-1993.

\begin{tabular}{|c|c|c|c|c|c|c|c|c|c|c|}
\hline \multirow{3}{*}{$\begin{array}{l}\text { Index } \\
\text { Sampling date }\end{array}$} & \multicolumn{4}{|c|}{1992 Treatment } & \multirow[b]{3}{*}{ P-value $^{l}$} & \multicolumn{4}{|c|}{1993 Treatment } & \multirow[b]{3}{*}{ P-value ${ }^{1}$} \\
\hline & \multicolumn{2}{|c|}{ Control } & \multicolumn{2}{|c|}{ Treated } & & \multicolumn{2}{|c|}{ Control } & \multicolumn{2}{|c|}{ Treated } & \\
\hline & $\overline{\mathrm{x}}$ & SD & $\overline{\mathrm{x}}$ & SD & & $\overline{\mathbf{x}}$ & $\mathrm{SD}$ & $\mathrm{x}$ & SD & \\
\hline \multicolumn{11}{|c|}{ Richness (No. species/13 ha) } \\
\hline Pre-treatment & 44 & 3 & 46 & 6 & 069 & 53 & 8 & 56 & 5 & 0.30 \\
\hline Post-treatment & 46 & 9 & 39 & 10 & 0.10 & 50 & 8 & 37 & 13 & 0.27 \\
\hline \multicolumn{11}{|l|}{ Evenness } \\
\hline Pre-treatment & 0.72 & 0.10 & 0.77 & 0.07 & 0.01 & 0.82 & 0.01 & 0.83 & 0.02 & 0.38 \\
\hline Post-treatment & 0.81 & 0.01 & 0.82 & 0.01 & 0.53 & 0.86 & 0.00 & 0.86 & 0.02 & 0.51 \\
\hline \multicolumn{11}{|l|}{ Shannon's index } \\
\hline Pre-treatment & 3.09 & 0.04 & 3.19 & 0.38 & 0.34 & 3.40 & 0.13 & 3.46 & 0.06 & 0.09 \\
\hline Post-treatment & 3.20 & 0.26 & 3.06 & 0.30 & 0.14 & 3.30 & 0.17 & 3.07 & 0.25 & 0.18 \\
\hline \multicolumn{11}{|l|}{ Beta diversity } \\
\hline Pre-treatment & 0.57 & 0.03 & 0.61 & 007 & $0.5 ?$ & 055 & 009 & 0.66 & 0.08 & 0.08 \\
\hline Post-treatment & 0.61 & 0.07 & 0.63 & 0.08 & 0.65 & 0.66 & 0.02 & 0.69 & 0.04 & 0.89 \\
\hline \multicolumn{11}{|l|}{ Rareness } \\
\hline Pre-treatment & 1.88 & 0.04 & 1.92 & 0.04 & 0.01 & 1.97 & 0.02 & 1.98 & 0.04 & 0.40 \\
\hline Post-treatment & 1.93 & 0.02 & 1.94 & 0.04 & 0.55 & 1.95 & 0.02 & 1.95 & 0.11 & 0.77 \\
\hline
\end{tabular}

${ }^{1}$ Control and herbicide treatment means were compared using $t$-tests for pre-treatment data and using repeated measures ANOVA on the post-treatment data for the 1992 herbicide application. Analysis of the 1993 treatment involved comparing the control and herbicide treatment means using $t$-tests for the pre-treatment and post-treatment data.

species are also an important food source for deer during late winter. Reduction of California loosestrife and Indian mallow may also have been undesirable since these species are sources of food for deer. Since Texas broomweed (Xanthocephalum texanum Gray) is not used as forage by wildlife or livestock, reduction in canopy cover was possibly beneficial. We did not determine the long-term effects of the herbicide treatment on canopy cover of these species and results should be considered in the context that the reduction in canopy cover of forbs following herbicide treatments is often temporary (Scifres 1980).

\section{Small Mammals and Birds}

Structural and compositional changes which occurred in the vegetation community did not appear to impact rodent or avian communities. Explanations for the lack of significant response by the rodent and avian communities during the course of this study include adaptation to the changes in community structure and composition, delayed response to the changes, or low power of statistical tests to detect significant differences because of the low number of replications. Major changes in the community following herbicide treatment included a decrease in mesquite and forb cover and a reduction of selected forbs such as western ragweed.

Table 5. Results of small mammal trapping during 4,998 trap nights on herbicide-treated and untreated (control) plots before and after application of triclopyr + picloram to control honey mesquite on the Rob and Bessie Welder Wildlife Foundation Refuge, San Patricio County, Texas, $1992-1993$.

\begin{tabular}{|c|c|c|c|c|c|c|c|c|c|c|}
\hline \multirow{3}{*}{$\begin{array}{l}\text { Attribute } \\
\text { Sampling date }\end{array}$} & \multicolumn{4}{|c|}{1992 Treatment } & \multirow[b]{3}{*}{ P-value ${ }^{1}$} & \multicolumn{4}{|c|}{1993 Treatment } & \multirow[b]{3}{*}{ P-value } \\
\hline & \multicolumn{2}{|c|}{ Control } & \multicolumn{2}{|c|}{ Treated } & & \multicolumn{2}{|c|}{ Control } & \multicolumn{2}{|c|}{ Treated } & \\
\hline & $\overline{\mathrm{x}}$ & SD & $\bar{x}$ & SD & & $\bar{x}$ & SD & $\overline{\mathbf{x}}$ & SD & \\
\hline \multicolumn{11}{|c|}{ Relative density (\# captures in 4,998 trap nights) } \\
\hline Pre-treatment & 4 & 2 & 19 & 20 & 0.28 & 17 & 8 & 20 & 10 & 0.58 \\
\hline Post-treatment & 12 & 8 & 10 & 6 & 0.50 & 6 & 6 & 12 & 14 & 0.27 \\
\hline \multicolumn{11}{|c|}{ Deer mouse (Peromyscus leucopus Rafinesque) frequency $(\%)$} \\
\hline Pre treatment & 25 & 43 & 33 & 24 & 0.28 & 39 & 20 & 45 & 10 & 0.77 \\
\hline Post-treatment & 46 & 10 & 37 & 9 & 0.57 & 53 & 21 & 51 & 38 & 0.64 \\
\hline \multicolumn{11}{|c|}{ Hispid cotton rat (Sigmodon hispidus Say and Ord) frequency (\%) } \\
\hline Pro-treatment & 65 & 38 & 65 & 27 & 0.85 & 44 & 22 & 51 & 12 & 0.48 \\
\hline Post-treatment & 28 & 23 & 32 & 28 & 0.64 & 11 & 19 & 19 & 10 & 0.42 \\
\hline \multicolumn{11}{|c|}{ Southern Plains Wood rat (Neotoma micropus Baird) frequency (\%) } \\
\hline Pre-treatment & 10 & 17 & 1 & 1 & 0.59 & 17 & 16 & 4 & 4 & 0.42 \\
\hline Post-treatment & 27 & 13 & 32 & 37 & 0.38 & 36 & 13 & 30 & 28 & 0.50 \\
\hline \multicolumn{11}{|c|}{ Pigmy mouse (Baiomys taylori Thomas) frequency $(\%)$} \\
\hline Pre-treatment & 0 & 0 & 3 & 2 & - & 0 & 0 & 0 & 0 & - \\
\hline Post-treatment & 0 & 0 & 0 & 0 & - & 0 & 0 & 0 & 0 & - \\
\hline
\end{tabular}

${ }^{1}$ Control and herbicide treatment means were compared using $t$-tests for pre-treatment data and using repeated measures ANOVA on the post-treatment data for the 1992 herbicide application. Analysis of the 1993 treatment involved comparing the control and herbicide treatment means using $t$-tests for the pre-treatment and post-treatment data. 
Table 6. Mean $(n=3)$ small mammal richness $(\# / 0.49$ ha) and Shannon's index within herbicide-treated and untreated (control) plots before and after application of triclopyr + picloram to control honey mesquite on the Rob and Bessie Welder Wildlife Foundation Refuge, San Patricio County, Texas, 1992-1993.

\begin{tabular}{|c|c|c|c|c|c|}
\hline \multirow{2}{*}{$\begin{array}{l}\text { Date } \\
\text { Treatment }\end{array}$} & \multicolumn{3}{|c|}{ Species richness/0.49 ha } & \multicolumn{2}{|c|}{ Shannon's index } \\
\hline & $\overline{\mathbf{x}}$ & SD & $\overline{\mathbf{x}}$ & & SD \\
\hline \multicolumn{6}{|c|}{ Pre-treatment 1992} \\
\hline Control & 2 & 0.6 & 0.39 & & 0.34 \\
\hline Herbicide 1992 & 3 & 1.0 & 0.66 & & 0.22 \\
\hline P-value ${ }^{1}$ & \multicolumn{3}{|c|}{0.03} & \multicolumn{2}{|l|}{0.26} \\
\hline \multicolumn{6}{|c|}{ Post-treatment 1992} \\
\hline Control & 3 & 0.0 & 0.92 & & 0.15 \\
\hline Herbicide 1992 & 3 & 0.6 & 0.70 & & 0.11 \\
\hline P-value ${ }^{1}$ & \multicolumn{3}{|c|}{0.70} & \multicolumn{2}{|l|}{0.44} \\
\hline \multicolumn{6}{|l|}{ Pre-treatment 1993} \\
\hline Control & 3 & 0.0 & 0.92 & & 0.15 \\
\hline Herbicide 1993 & 3 & 0.6 & 0.80 & & 0.11 \\
\hline P-value ${ }^{l}$ & \multicolumn{3}{|c|}{0.69} & \multicolumn{2}{|l|}{0.31} \\
\hline \multicolumn{6}{|c|}{ Post-treatment 1993} \\
\hline Control & 2 & 0.6 & 0.78 & & 0.28 \\
\hline Herbicide 1993 & 3 & 0.0 & 0.79 & & 0.13 \\
\hline P-value ${ }^{l}$ & \multicolumn{3}{|c|}{0.47} & \multicolumn{2}{|l|}{0.06} \\
\hline
\end{tabular}

${ }^{1}$ Control and herbicide treatment means were compared using $t$-tests for pre-treatment data and using repeated measures ANOVA on the post-treatment data for the 1992 herbicide application. Analysis of the 1993 treatment involved comparing the control and herbicide treatment means using 1 -tests for the pre-treatment and post-treatment data.

The changes may have been within the threshold of habitat requirements for the species studied. Impacts of control of mesquite with triclopyr + picloram on the plant community were not as drastic as the effects of mechanical manipulation would have been. Community response to the treatment also may have been delayed. Small rodents tend to have a high turnover rate and sufficient resources may have been available during the course of this study to maintain population levels. Effects on reproduction and survival may not have manifested during this study.
Table 8. Avian species mean $(n=3)$ richness $(\# / 13$ ha) and Shannon's index within herbicide-treated and untreated (control) plots before and after application of triclopyr + picloram to control honey mesquite on the Rob and Bessie Welder Wildlife Foundation Refuge, San Patricio County, Texas, 1992-1993.

\begin{tabular}{|c|c|c|c|c|}
\hline \multirow{2}{*}{$\begin{array}{l}\text { Date } \\
\text { Treatment }\end{array}$} & \multicolumn{2}{|c|}{ Species richness $/ 13$ ha } & \multicolumn{2}{|c|}{ Shannon's inder } \\
\hline & $\overline{\mathrm{x}}$ & $\mathrm{SD}$ & $\overline{\bar{x}}$ & SD \\
\hline \multicolumn{5}{|l|}{ Pre-treatment 1992} \\
\hline Control & 11 & 5 & 1.84 & 0.21 \\
\hline Herbicide 1992 & 16 & 6 & 2.20 & 0.26 \\
\hline P-value ${ }^{1}$ & \multicolumn{2}{|c|}{0.81} & \multicolumn{2}{|c|}{0.90} \\
\hline \multicolumn{5}{|c|}{ Post-treatment 1992} \\
\hline Control & 13 & 6 & 2.25 & 0.44 \\
\hline Herbicide 1992 & 9 & 3 & 1.87 & 0.30 \\
\hline$P$-value ${ }^{l}$ & \multicolumn{2}{|c|}{0.57} & \multicolumn{2}{|c|}{0.77} \\
\hline
\end{tabular}

${ }^{1}$ Control and herbicide treatment means were compared using $t$-tests for pre-treatment data and using repeated measures ANOVA on the post-treatment data for the 1992 herbjcide application.

The high mobility of avian species could also mask negative impacts of the treatment. Patterns of use of treated areas may have shifted following treatment. Decreased cover, resulting in increased availability of seeds and insects, could have resulted in the treated areas receiving greater use for foraging by granivorous and insectivorous birds. The same birds may have used adjacent sites for nesting or roosting until appropriate cover became available in treated sites.

Based on our results, triclopyr + picloram application to 13.3ha plots in a mesquite-mixed grass community does not appear to negatively impact plant and vertebrate species richness and diversity during the first 2 years posttreatment when annual rainfall is $16 \%$ above average. Additional research is needed to determine if application of the herbicide impacts plant and vertebrate species richness and diversity during years of average or below-average rainfall or in other plant communities.

Table 7. Mean $(n=3)$ frequency $(\%)$ for select avian species within herhicide-treated and untreated (control) plots before and after application of triclopyr + picloram to control honey mesquite on the Rob and Bessie Welder Wildlife Foundation Refuge, San Patricio County, Texas, 1992-1993.

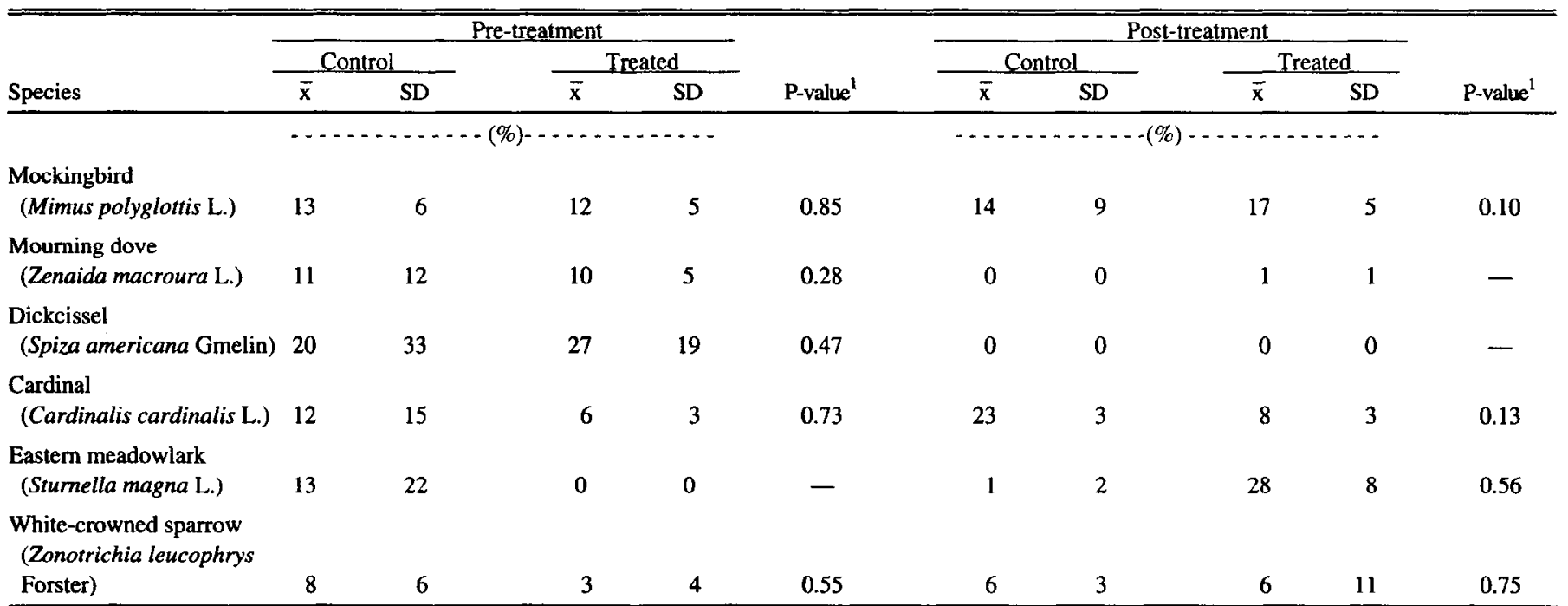

Control and herbicide treatment means were compared using $t$-tests for pre-treatment data and using repeated measures ANOVA on the post-treatment data for the 1992 herbicide application. 


\section{Literature Cited}

Arnold, L.A. and D.L. Drawe. 1979. Seasonal food habits of whitetailed deer in the south Texas Plains. J. Range Manage. 32:175-178.

Beasom, S.L., J.M. Inglis, and C.J. Scifres. 1982. Vegetation and white-tailed deer responses to herbicide treatment of a mesquite drainage habitat type. J. Range Manage. 35:790-794.

Biondini, M.E., A.A. Steuter, and C.E. Grygiel. 1989. Seasonal fire effects on the diversity patterns, spatial distribution and community structure of forbs in the Northern Mixed Prairie, USA. Vegetatio 85:21-31.

Chambers, F.C. and R.W. Brown. 1983. Methods for vegetation sampling and analysis on revegetated mined lands. Gen. Tech. Rep. INT151, USDA For. Serv., Intermountain For. and Range Exp. Sta., Ogden, Utah.

Chamrad, A.D. and T.W. Box. 1968. Food habits of white-tailed deer in south Texas. J. Range Manage. 21:158-164.

Dahl, B.E., R.B. Wadley, M.R. George, and J.L. Talbot. 1971 Influence of site on mesquite mortality from 2,4,5-T. J. Range Manage. 24:210-215.

Day, G.I., S.D. Schemnitz, and R.D. Taber. 1980. Marking and capturing wild animals. pp 62-88 In: S. D. Schemnitz, ed. Wildlife management techniques manual. The Wildl. Soc. Washington, D.C.

Dormaar, J.F., M.A. Naeth, W.W. Willms, and D.S. Chanasyk. 1995. Effect of native prairie, crested wheatgrass (Agropyron cristatum (L.) Gaertn.) and Russian wildrye (Elymus junceus Fisch.) on soil chemical properties. J. Range Manage. 48:258-263.

Drawe, D.L., A.D. Chamrad, and T.W. Box. 1978. Plant communities of the Welder Wildlife Refuge, 2nd ed. Contrib. No. 5, revised. Welder Wildl. Found. Sinton, Texas. $38 \mathrm{pp}$.

Eberhardt, L.L. 1978. Transect methods for population studies. J. Wildl. Manage. 42:1-31.

Emlen, J.T. 1970. Habitat selection by birds following a forest fire. Ecol. 51:343-345.

Everitt, J.H. and D.L. Drawe. 1974. Spring food habits of white-tailed deer in the south Texas Plains. J. Range Manage. 27:15-20.

Flickinger, E.L. 1989. Observations of predation by red imported fire ants on live-trapped wild cotton rats. Tex. J. Sci. 41:225-229.

Hatch, S.L., K.C. Gandhi, and I.E. Brown. 1990. Checklist of the vascular plants of Texas. Texas Agr. Exp. Sta. Rep. MP-1655. College Station, Tex.

Janson, D. and J. Vegelius. 1981. Measures of ecological association. Oecologia (Berlin) 49:371-376.

Masser, M.P. and W.E. Grant. 1986. Fire ant-introduced trap mortality of small mammals in East-Central Texas. Southwestern Nat. 31:540-542.

McBryde, G. 1994. An estimated economic value for the Audubon Sabal Palm Sanctuary. Tex. J. Agr. and Nat. Res. 7:35-42.

McNaughton, S.J. 1985. Ecology of a grazing ecosystem: The Serengeti. Ecol. Mon. 55:259-294.

Morrison, M.L. and E.C. Meslow. 1984. Response of avian communities to herbicide-induced vegetation changes. J. Wildl. Manage 48:14-22.

Nolte, K.R., T.M. Gabor, M.W. Hehman, M.A. Asleson, T.E. Fulbright, and J.C. Rutledge. 1994. The long-term effects of brush management on vegetation diversity in ephemeral drainages. J. Range. Manage. 47:457-459.

Pielou, E.C. 1975. Ecological diversity. John Wiley \& Sons, New York, N.Y.

Pope, C.A., III. 1985. Agricultural productive and consumptive use components of rural land values in Texas. Amer. J. Agr. Econ. 67:81-86.

Porter, S.D. and W.R. Tschinkel. 1987. Foraging in Solenopsis invicta: effects of weather and season. Environ. Entomol. 16:802-808.

Rodgers, R.D. and M.L. Sexson. 1990. Impacts of extensive chemical control of sand sagebrush on breeding birds. J. Soil Water Conserv. July-August:494-497.

Santillo, D.J., P.W. Brown, and D.M. Leslie. Jr. 1989a. Response of song-birds to glyphosate-induced habitat changes on clearcuts. J. Wildl. Manage. 53:64-71
Santillo, D.J., D.M. Leslie, Jr, and P.W. Brown. 1989b. Responses of small mammals and habitat to glyphosate application on clearcuts. J. Wildl. Manage. 53:164-172.

SAS Institute Inc. 1988. SAS user's guide, 1988 edition. SAS Institute Inc., Cary, N.C.

Scheiner, S.M. 1992. Measuring pattern diversity. Ecology. 73:1860-1867.

Scifres, C.J. 1980. Brush management: Principles and practices for Texas and the southwest. Texas A\&M University Press, College Station, Tex.

Scifres, C.J. and B.II. Koerth. 1986. Habitat alterations in mixed brush from variable rate herbicide patterns. Wildl. Soc. Bull. 11:345-356.

Snedecor, G.W. and W.G. Cochran. 1967. Statistical methods. 6th ed. The Iowa State University Press, Ames, Iowa. 593pp.

Stoddard, I.A., A.K. Smith, and T.W. Box. 1975. Range management. 3rd ed. McGraw-Hill Book Co., New York, N.Y.

Sullivan, T.P. and D.S. Sullivan. 1982. Responses of small mammal populations to a forest herbicide application in a 20-year-old conifer plantation. J. Appl. Ecol. 19:95-106.

Tazik, D.J., S.D. Warren, V.E. Diersing, R.R. Shaw, R.J. Brozka, C. F. Bagley, and W.R. Whitworth. 1991. U. S. Army land conditiontrend analysis field methods. CEHSC-FN Tech. Note 420-74-3. 66pp.

Tilman, D. and J.A. Downing. 1994. Biodiversity and stability in grasslands. Nature 367:363-365.

Wakely, J.S. 1987. Avian line transect methods: Section 6.3.2, U.S. Army Corps Eng. Wildl. Resour. Manage. Tech. Rep. EL-87-5, U.S. Army Eng. Waterways Exp. Sta., Vicksburg, Miss. 39pp.

Warren R.J. and L.J. Krysl. 1983. White-tailed deer food habits and nutritional status as affected by grazing and deer harvest management. J. Range Manage. 36:104-109.

Webb, W.M. and F. S. Guthery. 1983. Response of wildlife food plants to spring discing of mesquite rangelands in northwest Texas. J. Range Manage. 36:351-353.

Welch, T.G. 1993. Chemical weed and brush control suggestions for rangeland. Texas Agr. Ext. Serv., Texas A\&M Univ., College Station. 10M-2-93.

West, N.E. 1993. Biodiversity of rangelands. J. Range Manage. 46:2-13.

Wray,T. and R.C. Whitmore. 1979. Effects of vegetation on nesting success of vesper sparrows. Auk 96:802-805. 